\title{
Levels of soluble fibrin monomer complexes , in the course of myocardial infarction
}

\author{
A. Nowak, B. Lipiński, and J. Drzewiecki \\ From the Third Medical Clinic Silesian School of Medicine, Katowice, \\ and the Department of Biochemistry Postgraduate Medical School, Warsaw, Poland
}

Plasma fibrinogen concentration, euglobulin clot lysis time, and soluble fibrin monomer complexes -in whole blood samples with protamine sulphate were determined in healthy subjects as well as in patients with atherosclerosis, coronary insufficiency, or myocardial infarction. Fibrinogen content and soluble fibrin monomer complex levels were higher while fibrinolytic activity was lower in -patients with atherosclerosis, coronary insufficiency, and myocardial infarction than in the healthy subjects. The blood soluble fibrin monomer complex level was significantly raised in patients with myocardial infarction as compared with patients with coronary insufficiency. These parameters, studied during the first three weeks in cases of myocardial infarction, showed a gradual increase of soluble fibrin monomer complex levels in poor risk patients while there was a conspicuous decrease in good risk patients. The determination of soluble fibrin monomer complexes in the whole blood can be useful for prognosis in myocardial infarction as well as for its differentiation from attacks of coronary insufficiency.

A decreased fibrinolytic activity and raised tibrinogen level in myocardial infarction have - been reported by several authors (Chakrabarti, Hocking, and Fearnley, 1969; Ogston, -1962; Protasova, 1969; Sikka et al., 1968; Szczeklik et al., 1958).

Recently Lipiński and Jeljaszewicz (1969) have put forward a hypothesis that an inhibition of fibrinolysis accompanied by an increase of soluble fibrin monomer complexes in blood are responsible for a hypercoagulable state.

The aim of the present work was to study the dynamics of changes in these monomer complexes and fibrinogen level in blood as * well as fibrinolytic activity in patients with myocardial infarction in comparison to groups of healthy subjects, atherosclerotic patients, and those with coronary artery disease.

$-$

\section{Material and methods}

'The study was carried out on inpatients. Group $A$ comprised 40 healthy subjects (mean age 30 years); group $B$ consisted of 23 patients with atherosclerosis (mean age 60 years); group $C$ of 16 patients with coronary insufficiency (mean age 49 years); and group $D$ of 14 patients with myocardial infarction (mean age 53 years).

Fasting blood samples were drawn from antecubital veins in the morning.

Received 21 July 1971.
In the patients with myocardial infarction, blood was collected at intervals of one to three days for three weeks after the onset of infarction. This group was divided into two subgroups according to the following criteria:

a) 'Poor risk' group comprised patients with circulatory insufficiency, persistent and frequent coronary pain attacks, and or cardiac arrhythmias during the whole period of observation. Two out of 5 patients in this group died in the third week after the onset of infarction.

b) 'Good risk' group comprised patients showing no such symptoms as described above. None of 9 patients of this group died.

The level of soluble fibrin monomer complexes in blood was determined by the method described by Lipiński, Kotelba-Witkowska, and Zajdel (1970). The method consists in the addition of O. I ml I per cent protamine sulphate (Biomed, Poland) in saline to $1 \mathrm{ml}$ oxalated blood. After 5 minutes of incubation at $25^{\circ} \mathrm{C}$ the mixture was transferred into a nonheparinized microhaematocrit tube, sealed, and centrifuged for 2 minutes at $12,000 \mathrm{rpm}$. The level of soluble fibrin monomer complexes was expressed as a percentage of white precipitate formed over a layer of the red cells with respect to the total volume of the sample.

Fibrinolytic activity was determined by recording the euglobulin clot lysis time as described by Kowalski, Kopeć, and Niewiarowski (1959). Fibrinogen was determined by the method of Quick (195I). 
TABLE I Blood levels of soluble fibrin monomer complexes, fibrinogen, and fibrinolysis in 4 groups of subjects

\begin{tabular}{|c|c|c|c|c|c|c|c|}
\hline & $\begin{array}{l}\text { Patient } \\
\text { group }\end{array}$ & $\begin{array}{l}\text { No. of } \\
\text { patients }\end{array}$ & $\bar{X}$ & $S D$ & $\begin{array}{l}\text { Group } \\
\text { test }\end{array}$ & $t$ & $P$ \\
\hline \multirow{3}{*}{$\begin{array}{l}\text { Soluble fibrin monomer } \\
\text { complex }(\%)\end{array}$} & A & 40 & $I \cdot 9$ & $\pm I \cdot 4 I$ & $A: B$ & $6 \cdot 28$ & $<0.001$ \\
\hline & B & 23 & $\begin{array}{l}2.9 \\
2.0\end{array}$ & $\begin{array}{l} \pm 0.79 \\
+0.71\end{array}$ & $\begin{array}{l}A: C \\
A: D\end{array}$ & $\begin{array}{l}7 \cdot 13 \\
0 \cdot 88\end{array}$ & $\begin{array}{l}<0.001 \\
<0.001\end{array}$ \\
\hline & D & I4 & 4.4 & $\pm I \cdot 44$ & C:D & 3.45 & $<0.01$ \\
\hline \multirow{4}{*}{$\begin{array}{l}\text { Euglobulin fibrinolysis } \\
\text { (min) }\end{array}$} & $\bar{A}$ & 33 & 163 & \pm 57 & $A: B$ & $1 \cdot 85$ & $>0.05$ \\
\hline & B & 20 & 195 & \pm 78 & $A: C$ & $1 \cdot 58$ & $>0.05$ \\
\hline & C & 16 & 191 & \pm 68 & A:D & $4 \cdot 33$ & $<0.001$ \\
\hline & D & 14 & 291 & \pm 154 & C:D & $2 \cdot 47$ & $<0.02$ \\
\hline \multirow[t]{4}{*}{ Fibrinogen $(\mathrm{mg} / \mathrm{roO} \mathrm{ml})$} & $\bar{A}$ & 38 & 310 & \pm IIo & $A: B$ & $3 \cdot 01$ & $<0.01$ \\
\hline & B & 23 & 420 & \pm 170 & $\mathrm{~A}: \mathrm{C}$ & $I \cdot I 7$ & $>0.05$ \\
\hline & C & 16 & 350 & \pm 130 & A:D & 4.59 & $<0.001$ \\
\hline & D & 14 & 500 & \pm 170 & C:D & $2 \cdot 95$ & $<0.01$ \\
\hline
\end{tabular}

A - Healthy subjects; B - Atherosclerosis; C - Coronary insufficiency; D - Myocardial infarction. The results represent the mean values of determinations made during the first 3 days after the onset of infarction.

\section{Results}

The results of the determination of the monomer complex level and fibrinogen content in the blood, as well as the fibrinolytic activity are presented in Table $I$.

It is evident from Table I that the level in the patients with myocardial infarction, atherosclerosis, and coronary insufficiency, is significantly higher than in the healthy subjects. Moreover, the content in blood of patients with myocardial infarction was significantly higher than in those with coronary insufficiency.

Conspicuous inhibition of fibrinolysis was observed in patients with myocardial infarction in comparison with healthy subjects and patients with coronary insufficiency.

The fibrinogen level was significantly raised in patients with myocardial infarction compared with healthy subjects, patients with atherosclerosis, and those with coronary insufficiency. The behaviour of soluble fibrin monomer complexes, fibrinogen level, and fibrinolysis time in 3 consecutive weeks after the onset of infarction is illustrated in Table 2. These results indicate that in patients with a good prognosis ('good risk' group) an obvious decrease in the monomer complexes gradually occurs, while in the patients with a bad prognosis ('poor risk') their blood levels significantly increase in the third week of observation $(\mathbf{P}<0.001)$.

The difference between the blood soluble fibrin monomer complex level in both groups of patients in the third week is highly significant $(P<0.01)$, whereas in the first week it is insignificant.

No significant alteration in behaviour of fibrinogen level and fibrinolysis was observed in both groups of patients in the consecutive weeks after the onset of the infarction.

The dynamic changes in the level of soluble fibrin monomer complexes, fibrinogen content, and fibrinolysis in one patient with a

TABLE 2 Behaviour of soluble fibrin monomer complexes, fibrinogen, and fibrinolysis in myocardial infarction patients in consecutive weeks after onset of infarction

\begin{tabular}{|c|c|c|c|c|c|}
\hline & \multirow{3}{*}{$\begin{array}{l}\text { Weeks after } \\
\text { onset of } \\
\text { infarction }\end{array}$} & \multicolumn{4}{|c|}{ Patients with myocardial infarction } \\
\hline & & \multicolumn{2}{|c|}{$\begin{array}{l}\text { 'Good risk' } \\
\text { ( } 9 \text { persons - } 55 \text { determinations) }\end{array}$} & \multicolumn{2}{|c|}{$\begin{array}{l}\text { 'Poor risk' } \\
\text { ( } 5 \text { persons }-40 \text { determinations) }\end{array}$} \\
\hline & & $\bar{X}$ & $S D$ & $\bar{X}$ & $S D$ \\
\hline $\begin{array}{l}\text { Soluble fibrin monomer } \\
\text { complexes }(\%)\end{array}$ & $\begin{array}{l}\text { Ist } \\
\text { 2nd } \\
\text { 3rd }\end{array}$ & $\begin{array}{l}3 \cdot 9 \\
3 \cdot 6 \\
2 \cdot 7\end{array}$ & $\begin{array}{l} \pm 1 \\
\pm 0.9 \\
\pm 0.23\end{array}$ & $\begin{array}{l}4 \cdot 7 \\
4 \cdot 5 \\
6 \cdot 1\end{array}$ & $\begin{array}{l} \pm I \\
\pm I \cdot 9 \\
\pm I \cdot I\end{array}$ \\
\hline $\begin{array}{l}\text { Euglobulin fibrinolysis } \\
\text { (min) }\end{array}$ & $\begin{array}{l}\text { Ist } \\
\text { 2nd } \\
\text { 3rd }\end{array}$ & $\begin{array}{l}240 \\
260 \\
240\end{array}$ & $\begin{array}{l} \pm 104 \\
\pm 153 \\
\pm 67\end{array}$ & $\begin{array}{l}430 \\
280 \\
340\end{array}$ & $\begin{array}{r} \pm 270 \\
\pm 43 \\
\pm 140\end{array}$ \\
\hline Fibrinogen $(\mathrm{mg} / 100 \mathrm{ml})$ & $\begin{array}{l}\text { ist } \\
\text { 2nd } \\
\text { 3rd }\end{array}$ & $\begin{array}{l}450 \\
440 \\
450\end{array}$ & $\begin{array}{r} \pm 160 \\
\pm 70 \\
\pm 150\end{array}$ & $\begin{array}{l}340 \\
570 \\
470 \\
500\end{array}$ & $\begin{array}{r} \pm 40 \\
\pm 70 \\
\pm 180\end{array}$ \\
\hline
\end{tabular}


good prognosis and one with a bad prognosis are shown in the Figure.

It is evident from this Figure that in the patient with a mild course of myocardial infarction the level was initially increased but returned to normal values on the seventh day of observation and remained constant during the whole period of observation. Corresponding changes were found in the fibrinogen level and fibrinolytic activity in blood. In the subject with 'poor risk', suffering from recurrent coronary attacks and cardiac arrhythmia, the level fluctuated considerably till the eighth day, and then considerably exceeded the normal value till the end of observation. This patient survived. Raised fibrinogen concentration and inhibition of fibrinolysis were observed in the patient only during the first week after the onset of infarction.

\section{Discussion}

The results of our study concerning fibrinogen and fibrinolysis in myocardial infarction agree with the results reported by other

FIG. Changes in the level of soluble fibrin monomer complexes (SFMC) and fibrinogen as well as fibrinolytic activity in the course of myocardial infarction in two patients.
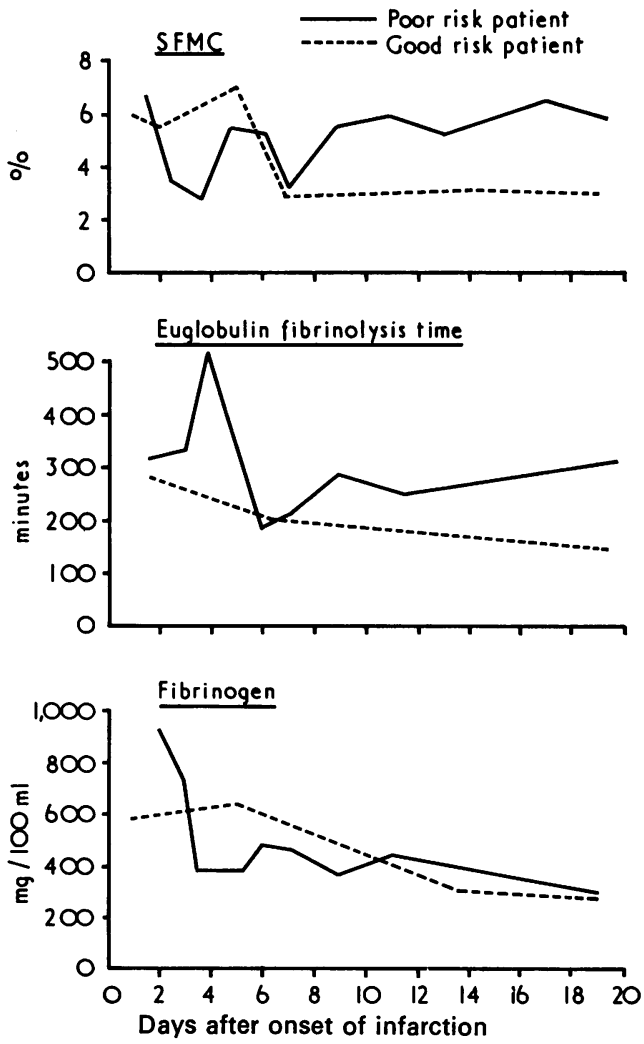

authors (Szczeklik et al., 1958; Ogston, 1962; Chakrabarti et al., 1968; Sikka et al., 1968; Moschos et al., 1969; Protasova, 1969).

It was previously reported by Lipiński and Worowski (1968) that the soluble fibrin monomer complex content in the plasma of patients with myocardial infarction was considerably increased. These results were obtained by a single determination in a small group of patients using a different method from that applied in the present work. The results of the present study indicate that an increase of the level in circulating blood occurs in all the clinical forms of atherosclerosis. The highest level was observed in patients with myocardial infarction: this phenomenon was steady. During the first week after the onset of infarction the blood level of soluble fibrin monomer complexes was above the normal values in 85 per cent of the subjects. It is worth noting that in healthy subjects the content in blood is constant (Lipiński et al., I970).

It is interesting to discover whether the process of myocardial infarction is accompanied by a hypercoagulable state. At present we cannot say whether the increased level of soluble fibrin monomer complexes is a cause or a result of myocardial infarction. Persisting high levels in the blood and their increase together with continuing clinical symptoms suggest the existence of a hypercoagulable state. It is possible that such hypercoagulability is the result of a disturbance in the dynamic equilibrium between blood clotting and fibrinolysis (Astrup, 1959; Copley, 1957; Duguid, I949).

This possibility is corroborated by the fact that the fibrinolytic activity of blood is lower in patients with myocardial infarction and coronary insufficiency.

The question arises, what is the role of increased level of soluble fibrin monomer complexes in myocardial infarction?

It is known from the studies in vitro that these complexes can be paracoagulated (non enzymatic precipitation) by. a number of physicochemical agents. These include basic proteins such as protamine sulphate and other basic tissue proteins, lysozyme and platelet factor 4 (Stewart and Niewiarowski, 1969; Kopeć, Wȩgrzynowicz, and Latallo, 1970).

The paracoagulated precipitates of the soluble fibrin monomer complexes show by electron microscopy a characteristic periodicity typical of fibrin (Horn, Hawiger, and Collins, 1969).

Theoretically the paracoagulation reaction of soluble fibrin monomer complexes may occur in circulating blood. This is particularly 
likely when the blood level is increased as was observed in hypercoagulable states (Lipiński and Jeljaszewicz, I969; Lipiński et al., 1967), and in myocardial infarction as well. The increased content of these monomer complexes represents a potential substrate for the paracoagulation induced with basic protein which may be released from blood cells (platelets, leucocytes) or tissue cells into the blood stream. This may result in local precipitation of amorphous masses of parafibrin. It can be speculated that the increased content of these soluble monomer complexes in patients with a bad prognosis ('poor risk' group) may contribute to the postinfarction symptoms. Because of its simplicity and rapidity, the test for these complexes may be of diagnostic and prognostic value in myocardial infarction and may provide important information even at the bedside.

The behaviour of these soluble fibrin monomer complex levels in blood has practical importance in the differentiation of attacks of coronary insufficiency and infarction.

This work was supported by the Polish Academy of Science.

\section{References}

Astrup, T. (1959). Role of blood coagulation and fibrinolysis in the pathogenesis of arteriosclerosis. In Connective Tissue, Thrombosis and Atherosclerosis, p. 223. Ed. by I. H. Page. Academic Press, New York and London.

Chakrabarti, R., Hocking, E. D., and Fearnley, G. R. (1969). Reaction pattern to three stresses - electroplexy, surgery, and myocardial infarction - of fibrinolysis and plasma fibrinogen. Fournal of Clinical Pathology, 22, 659.

Chakrabarti, R., Hocking, E. D., Fearnley, G. R., Mann, R. D., Attwell, T. N., and Jackson, D. (1968). Fibrinolytic activity and coronary-artery disease. Lancet, r, 987.

Copley, A. L. (1957). Fibrinolysis and atherosclerosis. Lancet, $\mathrm{I}, 102$.

Duguid, J. B. (1949). Pathogenesis of atherosclerosis. Lancet, 2, 925.

Horn, R. G., Hawiger, J., and Collins, R. D. (1969). Electron microscopy of fibrin-like precipitate formed during the paracoagulation reaction between soluble fibrin monomer complexes and pro- tamine sulphate. British fournal of Haematology, I7, 463 .

Kopeć, M., Węgrzynowicz, Z., and Latallo, Z. S. (1970). Soluble fibrin complexes and a new specific test for their detection. Thrombosis et diathesis haemorrhagica, Suppl. 39, 219.

Kowalski, E., Kopeć, M., and Niewiarowski, S. (1959). An evaluation of the euglobulin method for the determination of fibrinolysis. Fournal of Clinical Pathology, 12, 215.

Lipiński, B., and Jeljaszewicz, J. (1969). A hypothesis for the pathogenesis of the generalized Shwartzman reaction. Fournal of Infectious Diseases, 120, I60.

Lipiński, B., Kotelba-Witkowska, B., and Zajdel, M. (1970). The level of soluble fibrin monomer complexes in blood of healthy humans. Abstracts XIIIth International Congress of Hematology, Munich.

Lipiński, B., Wȩgrzynowicz, Z., Budzyński, A. Z., Kopeć, M., Latallo, Z. S., and Kowalski, E. (1967). Soluble unclottable complexes formed in the presence of fibrinogen degradation products (FDP) during the fibrinogen-fibrin conversion and their potential significance in pathology. Thrombosis et diathesis haemorrhagica, 17, 65 .

Lipiński, B., and Worowski, K. (I968). Detection of soluble fibrin monomer complexes in blood by means of protamine sulphate test. Thrombosis et diathesis haemorrhagica, 20, 44.

Moschos, C. B., Lehan, P. H., Koroxenidis, G. T., Weisse, A. B., Oldewurtel, H. A., and Regan, T. J. (1969). Regional and systemic clotting and fibrinolytic activity after myocardial injury. American Fournal of Physiology, 216, 308.

Ogston, D. (1962). Serum mucoproteins and plasma fibrinolytic activity in coronary-artery disease. British Medical fournal, I, I242.

Protasova, N. S. (1969). Nekotorye pokazateli svertyvaiushchei i protivosvertyvaiushchei sistemy krovi pri nekotorykh formakh koronarnoi nedostatochnosti. Klinicheskaya meditsina, 47, 54

Quick, A. J. (1951). The Physiology and Pathology of Haemostasis. Kimpton, London.

Sikka, K. K., Navani, H., Tiagi, G. K., and Nigam, D. N. (1968). Blood coagulation and fibrinolysis in relation to coronary artery disease. Indian fournal of Medical Research, 56, 4II.

Stewart, G. J., and Niewiarowski, S. (1969). Nonenzymatic polymerization of fibrinogen by protamine sulphate. Biochemica et biophysica Acta, I94, 462.

Szczeklik, E., Janiakowa, A., Orlowski, M., and Bogdanikowa, B. (1958). Biochemiczne podstawy wczesnego rozpoznawania miaźdżycy. Polski Tygodnik Lekarski, 13, 781.

Requests for reprints to Dr. Andrzej Nowak, 3rd Medical Clinic, Silesian School of Medicine, Katowice, ul. Francuska 20, Poland. 